\section{OPEN ACCESS}

Research Fellow at Faculty of Law, University of Oslo http://dx.doi.org/10.5339/ qproc.2013.fmd.8

(C) 2013 Clark, licensee Bloomsbury Qatar Foundation Journals. This is an open access article distributed under the terms of the Creative Commons Attribution license CC BY 3.0, which permits unrestricted use, distribution and reproduction in any medium, provided the original work is properly cited.

Family, Migration \& Dignity Special Issue

\title{
Discriminatory Policies \& Practices Intersectionality: The Promise \& the Challenge
}

Sevda Clark

\section{A STORY}

On one of my trips abroad I found myself in transit at Amsterdam airport. It is not an enjoyable experience (to say the least) on the best of flights, but this one experience will be one I continue to remember with a mixed sense of pain and disillusionment. Airport security controls are not something unfamiliar to me, and again, I braced myself as I carefully unpacked the dubious objects from my handbag - a clear plastic bag containing my lip gloss, perfume and anti-bacterial lotion among other indispensable items, as well as my laptop. I don't remember 'beeping' as I walked through the security gate. Yet, I was hailed to step aside by a female customs officer who had been deemed as appropriate to physically examine my body_rub it from head to toe to ensure that I had not carefully strapped any explosive devices to my admittedly fitted clothing. She looked noticeably indignant, and she made no attempt to hide her scorn. I breathed deeply and walked into the curtained area where I was to be further examined. I had the sense that I was in for something different this time. The whole time, the power dynamics that were at play were so thick that they almost took on a presence of their own.

With mocking disdain, and quite a heavy hand, she kneaded my body, and seemed somewhat disappointed that she had not discovered anything on me. Yet this 'guise' of appropriatenessthe gender of the person who was to effectuate the control and the curtain-turned into offering quite the opposite. At the hands and gaze of this woman, there was a clear attempt to humiliate, to dehumanize, to show me my place for that couple of minutes that I was subject to her power. Under any other circumstances, I would have case for a civil action for battery. While continuing to assert her power over me (after all, I could not catch my next flight if she did not let me pass), she kneeled down onto her knees and told me to lift my skirt. My heart beat fast as she examined me; I had a number of thoughts racing through my head. The instinctive lawyer's response yelled out at me: 'you know your rights Sevda! You don't have to put up with this. You do not deserve to be treated this way, and this act is surely against the regulations'. I thought of Hannah Arendt and her commentary in 'The Banality of Evil'. How in circumstances of systemic oppression, the simplest act, like switching on the lights at a concentration camp at night, can be vehicles for average people to participate in the inhumanity of the system.

This woman seemed to me to be acutely aware of her role as cog in this wheel. And her intention to me was crystal clear: to debase me. But the strongest thought that crossed my mind (and the one that won out in the end) was that I would not give her that satisfaction. The mental gymnastics thus began: 'Who does she think that she is? She is an employee of this airport'. So I said, with a concerted smile on my face: 'Thank you. This is nice service-in most places you have

Cite this article as: Clark S. Discriminatory Policies \& Practices. Intersectionality: The Promise \& the Challenge, QScience Proceedings 2013, Family, Migration \& Dignity Special Issue http:// dx.doi.org/10.5339/qproc.2013.fmd.8 
to pay for a service like this'. The tables had turned, and she had trouble disguising her shock caused by reasons other than my having spoken in clear, discernible English. She stood up quickly and scampered out of the curtained room making sure to avoid any eye contact.

\section{JUSTIFICATION AND INTRODUCTION}

I have dared to be more personal in my writing, to begin with a story. Using narrative technique is not new to the law ${ }^{\mathbf{1}}$, yet storytelling, "particularly storytelling written from an 'outsider's perspective', is a new form of legal writing that appears with increasing frequency on the pages of law reviews and specialized legal journals" . The outsider, as defined by one of the leading thinkers of critical legal theory, Richard Delgado, is a member of an 'outgroup ... whose marginality defines the boundaries of the mainstream, whose voice and perspective-whose consciousness-has been suppressed, devalued, and abnormalized’3 . Critical race feminism as 'a new off-shoot of both Critical Race theory and feminism' has similarly employed narrative techniques to bring a different voice ${ }^{4}$ into the ambit of critical legal thinking ${ }^{5}$. The voices heard in the narratives 'are not the judges and lawmakers who conventionally occupy our scholarly attention, but women: women who may also be minorities or members of other disadvantaged groups ${ }^{\mathbf{6}}$. The interest in marginalia can be seen as reflective of general academic interest studies of 'the other': the process of othering made famous in 1978 by Edward Said in his seminal study entitled Orientalism? ${ }^{\mathbf{7}}$. Indeed, such was the popularity of studies of marginalia in the late part of the Twentieth Century and early Twenty-First Century that it had led to claims that the centre had been decentred:

These days, centrality is distinctly uncool. The centre has been marginalised, and marginality, like Bohemian Manchester or Cornish fishing villages, is the place to be. With so many groups muscling in on them, from sexual and ethnic minorities to dog-on-a-rope anarchists, the margins have grown so crowded that there is now standing room only. Indeed, they have bulged to spread over most of the page. Like elitism, marginality isn't possible if too many people want to do it. It is an uncomfortable place, yet, oddly, it is where a lot of people want to be. In this sense it is a bit like Bangkok or the Aran islands.

Yet, when distinguished British literary theorist and critic Terry Eagleton wrote back in 2001 that outsiders were the new literary mainstream, he was conscious that although 'migrancy and marginality are nowadays much touted, [they are done so] more by cultural theorists than by refugees stowed away in lorries'. The practical realities and lived experiences of marginality for outsiders, migrants being a case in point, are such that they tend to fall between the cracks of anti-discrimination law - they continue to be on the peripheries of legal protection. Mari Matsuda, another leading critical race theorist coined the phrase 'looking to the bottom' to describe the process of 'adopting the perspective' of those who have experienced discrimination $\mathbf{8}^{\text {. }}$ Therefore, critical race theory posits that voices from the bottom have the power to open up new legal concepts. Paradoxically, bringing in the voices of outsiders has helped to make critical legal theory central to the legal canon.

This unlocking potential of critical race scholarship has encouraged me to redirect the scholarly lens upwards, from the lived experiences of those who are directly affected-those on the margins of society and law-to examine the (in)adequacy of antidiscrimination and equality law in redressing continuing marginalisation. In this paper I will offer the theory of intersectionality as the way forward to redressing existing gaps in antidiscrimination law for people at the intersections of multiple identities. After presenting the central thesis of intersectionality, and its history and continuing relevance, I will map a new 'site' of intersectional discrimination to demonstrate the dynamism and potential of the theory for women at the intersections - here, at the crossing of religion and gender, specifically cases of Muslim women. I will then move on to evaluate the European framework, looking specifically at cases decided by the European Court of Human Rights to distinctively argue that, though it can be seen to 
have adopted an 'intersectional' approach, the European Court has applied intersectionality disingenuously, resulting in furthering discrimination against Muslim women. Having demonstrated that an intersectional analysis has already made its way into court practice, I will then offer recommendations as to how intersectionality theory can be positively brought into the courts in order to afford genuine remedies to women at the intersections of religion and gender who are victims of discrimination.

\section{BACKGROUND}

Born out of the characteristic dissatisfaction with essentialism in feminism, Kimberlé Williams Crenshaw's influential legal theory of intersectionality made its entrance onto the world stage $^{9}$. As an advocate of anti-essentialism (the reaction against the existence of a common essential "woman") Crenshaw introduced and promoted the concept of intersectionality, in which gender is merely one of many axes of discrimination that are simultaneously intersecting and mutually reinforcing. At the heart of the critique is an attempt to demarginalise intersecting identities. This assumes that various aspects of identity do not operate independently and that a 'single-axis framework erases Black women in the conceptualization, identification and remediation of race and sex discrimination by limiting inquiry to the experiences of otherwiseprivileged members of the group ${ }^{\mathbf{1 0}}$. As part of her methodology, Crenshaw also 'looks to the bottom', taking the story of a key moment in feminist suffrage history and re-telling it, thereby looking from the perspectives of women of colour, whose stories are otherwise not told. She invokes the account of Sojourner Truth, an African-American slave who, with her powerful oratory, silences the crowd of male hecklers (an aspect of the 'feminist' story which is wellknown) but, also the white female activists at a women's rights conference. Many white women tried to silence Truth, in vein, when she stood up to make her famous speech, vividly portraying the horrors of slavery on women. Truth thereby declared her equality as a woman before not only men, but white women as well. In doing so, Crenshaw reminds us that 'this 19th-century Black feminist challenged not only patriarchy, but also white feminists wishing to embrace Black women's history to relinquish their vestedness in whiteness"11. "Ain't I a woman" thus became the catch cry of the intersectionality thesis in its attempt to re-imagine anti-discrimination law such that it captures the experiences of those on the margins of multiple intersecting identities, i.e., those at the grassroots:

It is ironic that those concerned with alleviating the ills of racism and sexism should adopt such a top-down approach to discrimination. If their efforts began instead with addressing the needs and problems of those who are most disadvantaged and with restructuring and remaking the world where necessary, then others who are singularly disadvantaged would also benefit. In addition it seems that placing those who currently are marginalized in the center is the most effective way to resist efforts to compartmentalize experiences ... 12

In her legal analysis, Crenshaw carefully examines North American case law to persuasively demonstrate that anti-discrimination law is failing to account for and remedy the discrimination faced by black American women. She uses the image of an intersection of streets:

Discrimination, like traffic through an intersection, may flow into one direction and it may flow into another. If an accident happens at an intersection, it can be caused by cars travelling from any number of directions, and, sometimes, from all of them. Similarly, if a black woman is harmed because she in the intersection, her injury could result from sex discrimination or race discrimination. ${ }^{\mathbf{1 3}}$

This image thus suggests that disadvantage at the intersection of multiple identities is likely, not only to be more severe ${ }^{\mathbf{1 4}}$ but it frustrates attempts to identify and allocate the responsible driver. 
Extending the analogy then, 'providing legal relief only when Black women show that their claims are based on race or on sex is analogous to calling an ambulance for the victim only after the driver responsible for the injuries is identified [...] In these cases the tendency seems to be that no driver is held responsible, no treatment is administered, and the involved parties simply get back in their cars and zoom away ${ }^{\prime 25}$. Thus, forcing women to filter their claims through specific single-axis categories, which are ill-suited to capturing their experiences, results in their claims not being heard and addressed.

\section{‘INTERSECTIONALITY FOR WHAT PURPOSE?’’6 THE TWO WINGS OF INTERSECTIONALITY}

Twenty years after its inception as a legal discourse, intersectionality has witnessed exponential growth in its recognition as an important paradigm for sociological and cultural studies, and has permeated disciplines ranging from social work, psychology to studies of the labour market ${ }^{\mathbf{1 7}}$. Not surprisingly, it's an increasingly contested concept, with criticisms that it is too complex $\mathbf{~}^{\mathbf{1 8}}$, internally conflicted ${ }^{\mathbf{1 9}}$, and, 'despite its popularity, there has been considerable confusion concerning what the concept actually means and how it can or should be applied in feminist inquiry ${ }^{\mathbf{2 0}}$. Further critics assert that intersectionality research 'became dominated by sociological investigations of law as a practice that was generally ill-suited to achieve change' and thus 'focused on law as a medium of performing identities, instead of exploring law's potential to contribute to overcoming disadvantage" ${ }^{\text {"21 }}$. Thus, as 'the definitions of intersectionality have advanced, so too have the challenges levied against the concept ${ }^{\mathbf{2 2}}$, exhibited further in Leslie McCall's discussion about the 'complexity' of intersectionality. ${ }^{\mathbf{2 3}}$

With the wealth of the literature available on the topic, it comes as no surprise perhaps that there are divergent views as to what an intersectional approach should look like, and for what purpose it should be pursued. Two threads-what I have termed the two wings of an intersectional analysis - can clearly be discerned: that intersectionality has a representational/ constructivist function, and secondly that it has a structural/systemic wing, without which the bird of equality and anti-discrimination cannot fly. Without looking to the structural oppressions, which lie at the heart of any claim of discrimination by those at the intersections of multiple identities, a state of equilibrium cannot be reached. This is precisely the concern that AfricanAmerican political scientist Jordan-Zachery expresses when it comes to 'doing intersectionality', that the 'new insights into the conceptualization and definition of intersectionality trouble its initial conceptualization' $\mathbf{2 4}$; that, while the way in which intersectionality is employed as a descriptive tool plays an important role, 'focusing only on the descriptive analysis ignores the liberation/political framework of intersectionality" ${ }^{\prime 25}$. This becomes acutely manifested in the cases brought by Muslim women situated at the intersections of religion and gender. It is suggested that the unique potential of intersectionality is its power to address disadvantage at the individual level_-giving a voice to the voiceless -and the structural level:

Intersectionality is sympathetic and applicable to both the structural level of analysis and individual-level phenomena via its domains of power thesis, which recognizes the various terrains on which politics plays out, both structural and interpersonal. In recognizing both aspects of 'intractable political problems', intersectionality bridges part of the theoretical gap between critical theory, which often faces the dilemma of overemphasis on structural explanations, and liberalism's privileging of the atomized individual. ${ }^{\mathbf{2 6}}$

\section{MAPPING NEW ‘SITES' OF INTERSECTIONAL DISCRIMINATION: THE CASE OF THE MUSLIM WOMAN}

I began with this paper with my own experience as a subject of this intersection. Further, in presenting this paper at the 'Conference on Migration, Family and Dignity', in Doha, in March 2012, I started by asking the questions posed by Jordan-Zachery, re-framed to fit where I find myself situated: 'Am I a Muslim woman or a woman who is a Muslim?' Like Jordan-Zachery, I find myself both excited and frustrated to be able to engage the issues intersectionality presents: 'My 
frustrations result from the fact that intersectionality is something I live every day. As I confront many of the challenges faced by [Muslim] women, it is not an academic exercise that I can simply leave behind when I turn off my computer. Intersectionality is not another analytical tool for me to pull out of my methods bag of tricks' ${ }^{27}$

It is my hope that by utilising my own experiences, and extrapolating to the way courts deal with discrimination against women similarly situated, I am able to illustrate the continuing efficacy of intersectional methodology. I have sought to use my narrative, in line with the classic approach of intersectional analysis as set out in the early narrative essays that defined the field, where "narratives take as their subject an individual or an individual's experience and extrapolate illustratively to the broader social location embodied by the individual. Often such groups are 'new' groups in the sense of having been named, defined, or elaborated upon in the process of deconstructing the original dimensions of the master category" ${ }^{\mathbf{2 8}}$. With the banning of religious symbols_including the Muslim headscarf, the hijab_across European states, I now turn to an analysis of the European Court of Human Rights, and its assessment of cases brought before it in the strong tide of Muslim women turning to the court for relief. The two cases that will be examined relate to the ban of the hijab in education: Dahlab v. Switzerland $(2001)^{\mathbf{2 9}}$ and Sahin v. Turkey $(2005)^{30}$.

\section{EVALUATION OF THE EUROPEAN FRAMEWORK: DISINGENUOUS INTERSECTIONALITY}

There has been a steadily increasing amount of literature on intersectional discrimination against Muslim women. In the recent volume on 'European Union Non-Discrimination Law and Intersectionality', various authors have tackled the issues that arise. Indeed, it is taken as a given that 'new manifestations of disadvantage at the intersections of ethnicity, language, religion and gender have emerged, with the consequence that the situation of Muslim and Romani women in Europe has become a seismograph revealing the effectiveness of the response of EU equality law to intersectional discrimination”31. Roseberry, for example, establishes that judicial approaches to bans of the Muslim headscarf are heavily influenced by the assimilationist paradigm, which makes a sharp distinction between identity and behaviour ${ }^{\mathbf{3 2}}$. Further, in her analysis of legal responses in France and Germany, Fehr posits that what is in fact at play is an intersectional analysis: what she terms 'intersectional prejudice'-that 'when one reflects on the core assumptions on which the laws are based, the headscarf controversies reveal more than mere coincidental intersectional discrimination" $\mathbf{3 3}$.

When brought before the Court, cases involving discrimination against Muslim women are usually framed as the freedom of religion or belief (Article 9) or discrimination on the basis of religion (Article 14), the prior being categorised as a human rights claim and the latter being a case falling under equality or non-discrimination law $\mathbf{3}^{\mathbf{3 4}}$. Yet, regardless of how the cases are framed, 'the courts have generally upheld these dress codes against both kinds of claims'35. In her newly published book, Howard reaches the same conclusion after an examination of the bans on religious symbols as a breach of the human right to freedom of religion, and as a breach of antidiscrimination laws. She concludes that the cases are more than likely to have exactly the same result ${ }^{\mathbf{3 6}}$. Thus, Muslim women are being discriminated against in education and their voices are not heard. Their cases are falling through the cracks, highlighting the urgent need to re-imagine the purposes of anti-discrimination law, with the methodology envisaged by Crenshaw-namely, to identify the "dominant ideologies" at play in structural discrimination by revealing deepseated underlying assumptions that permeate European society as a whole. ${ }^{\mathbf{3 7}}$

How can an intersectional approach assist here? It has been argued that the court has in fact utilised an intersectional approach when assessing such claims. I would like to probe this view in order to ascertain the shape that an intersectional analysis takes and for what purpose, by assessing the court's reasoning in two leading cases: Dahlab and Sahin. I hope to show that by looking to the second purpose of intersectionality theory - as a way of redressing structural 
injustices - the cases fall short of what can be properly defined as an intersectional framework. In Dahlab, a primary school teacher was prohibited from wearing the Islamic headscarf (hijab) in the performance of her teaching duties. Notably, there were no complaints from parents of the teacher's pupils. She complained of sex discrimination before the European Court of Human Rights and was dismissed by the court on the grounds that the measure 'was not directed at her as a member of the female sex' and that it is 'a measure that could also be applied to a man who, in similar circumstances, wore clothing that clearly identified him as a member of a different faith'. Here we have the prototypical intersectional situation, wherein a Muslim woman's case is dismissed because a Muslim man is not affected in the same way, and the ban does not significantly impinge on the rights of (non-Muslim) women, generally. This single-ground legalistic construction thus appears to completely reduce the reality of the lived experiences of Muslim women in the European context. In fact, in its analysis, the court goes further, to justify the prohibition in terms of the protection of gender equality:

'It cannot be denied outright that the wearing of a headscarf might have some kind of proselytising effect, seeing that it appears to be imposed on women by a precept which is laid down in the Koran and which, as the Federal Court noted, is hard to square with the principle of gender equality. It therefore appears difficult to reconcile the wearing of an Islamic headscarf with the message of tolerance, respect for others and, above all, equality and non-discrimination that all teachers in a democratic society must convey to their pupils.

Thus, without any attempt to explain its conclusions, the court summarily dismissed Dahlab's sex-discrimination claim by relying on the generalisation that the headscarf is irreconcilable with gender equality. By contrast, Leyla Sahin brought her case not as a discrimination case per se, but as a violation of her freedom of religion and belief. The applicant did rely on Article 14, but not on the single ground of gender but on religion. Notwithstanding, the judgment is thick with statements on gender equality. In its Sahin judgment, the court relied heavily on its decision in Dahlab. As Vakulenko observes, it is difficult to see how the court could have taken any account of the interaction of Sahin's gender with her religion (in the single-ground approach of the court, only the latter had been claimed), yet 'both gender and religion act as decisive structural forces in the judgment ${ }^{\mathbf{3}}$, albeit as necessarily at odds with each other. Due to the centrality of these structural forces in the judgment, the case is read by Vakulenko as "both a promise and a disappointment for intersectionality". The promise rests on the fact that structural forces are considered by the court. But its promise is also the very thing that undermines its analysisaccording to Vakulenko, the court makes no attempt to connect the context to the particular applicant. However, I respectfully differ from Vakulenko's analysis: Even if the court had directly applied this context of the antagonism between gender and religion to the individual applicant in this particular case, the structural forces identified (i.e. the context) is used to perpetuate existing misconceptions about Muslim women-assumptions that the court makes no attempt to explain; they are simply stated as given. Here, the term 'intersectional prejudice' manifests itself. According to the two wing approach identified above, I posit that this is not 'doing intersectionality'. In its conscious desire to lift those women who are marginalised from the structural discrimination that they continue to face, intersectionality cannot, by definition, be a negative process. Specifically, it cannot be used to deny women at the intersections of multiple identities a remedy against discrimination. This is the liberating power of intersectionality, that it seeks to re-imagine anti-discrimination law, though not only through a deconstruction of legal consciousness, but through the exposure of the 'otherness dynamic enthroned within the maintenance and perpetuation of white race consciousness' which 'seems to be at least as important as legal consciousness in supporting the dominant order'39. 


\section{INTERSECTIONALITY AS A WAY FORWARD FOR ANTI-DISCRIMINATION LAW}

As can be seen from the two leading cases of the European Court of Human Rights of Dahlab and Sahin, assessments as to broader structural forces and context have already made their way into court practice. Although this process has been heralded as promising in terms of intersectionality, I have shown that it falls short of satisfying the two 'wings' of intersectionality - what I have termed disingenuous intersectionality, at best. Thus, the adoption of a contextual approach per se cannot be seen as an intersectional approach. This must be accompanied by the added and essential requirement, speaking to the purpose of intersectionality, that it should be utilised with a view to lifting those on the margins out of structural discrimination. 'Doing intersectionality', therefore, necessitates that it is carried out with the conscious aim to redress entrenched and structural discrimination against people at the intersections of multiple identities. In 'doing intersectionality' one cannot underestimate the importance of paradigm-shifting-re-imagining equality law after having brought in to the centre the voices of the marginalised and victims of structural discrimination. This is what will ensure the continuing relevance of intersectionality for the law and that it is employed with the primary view to remedying structural injustice. This is not identity politics for its own sake, but with a fixed purpose. Thus, it is imminently flexible in order to continue to re-imagine the law as circumstances demand. It is showing that it is perfectly capable of being adopted into judicial and quasi-judicial settings. At the international human rights level, the Committee on Economic, Social and Cultural Rights (the oversight Committee for the International Covenant on Economic, Social and Cultural Rights 1966) has expressly recognised intersectional discrimination ${ }^{40}$. On the domestic scene, for the first time after having being devised over twenty years ago, the grounds of intersectional discrimination found its way into an act of parliament. In fact, it was (almost) codified into national law in the United Kingdom. That the provision has since been shelved indicates rigorous debate and steadfast attention to the cause.

\section{Endnotes:}

1. See for example, Daniel A. Farber and Suzanna Sherry, "Telling Stories out of School: An Essay on Legal Narratives," Stanford Law Review 45.4 (1993).; and Christopher J. Rideout, "Storytelling, Narrative Rationality, and Legal Persuasion," The Journal of the Legal Writing Institute 14 (1998).

2. See Kathryn Abrams, "Hearing the Call of Stories," California Law Review 79.4 (1991). for a useful overview of this body of legal scholarship. Legal storytelling had risen to such prominence in 1989, that it secured a symposium in a major law review: Symposium, 'Legal Storytelling' (1989) 87(8) The Michigan Law Review Association. See Jean Love, "The Value of Narrative in Legal Scholarship and Teaching," Journal of Gender Race \& Justice 87.2 (1998): 87.

3. Richard Delgado, "Storytelling for Oppositionists and Others: A Plea for Narrative," Michigan Law Review 87.8 (1989).. See also, Daniel G. Solórzano and Tara J. Yosso, "Critical Race Methodology: Counter-Storytelling as an Analytical Framework for Education Research," Qualitative Inquiry 8.1 (2002): 32. who define the methodology of 'counterstorytelling' as "a method of telling the stories of those people whose experiences are not often told (i.e. those on the margins of society)".

4. Feminist legal scholars who embrace this view often speak of women's 'different voice', borrowing from Carol Gilligan's ground-breaking book Carol Gilligan, In a Different Voice: Psychological Theory and Women's Development (London: Harvard University Press, 1982).

5. For a comprehensive overview of 'outsider' narrative scholarship written by feminists, see Abrams, "Hearing the Call of Stories."

6. Abrams, "Hearing the Call of Stories," 975.

7. Edward W. Said, Orientalism (N.Y.: Pantheon Books, 1978).

8. Mari J. Matsuda, "Looking to the Bottom: Critical Legal Studies and Reparations," Harvard Civil Rights-Civil Liberties Law Review 22.2 (1987). 
9. Kimberle Williams Crenshaw, "Demarginalizing the Intersection of Race and Sex: A Black Feminist Critique of Antidiscrimination Doctrine, Feminist Theory and Antiracist Politics," The University of Chicago Legal Forum (1989).. A precursor to Crenshaw's thesis can be found in the Combahee River Collective Statement, seen to be "among the most compelling documents produced by black feminists" (Harriet Sigerman, The Columbia Documentary History of American Women since 1941 (Columbia University Press, 2003) 316.). It was published in 1982 in the exceptional anthology Gloria T. Hull, Patricia Bell Scott and Barbara Smith, All the Women Are White, All the Blacks Are Men, but Some of Us Are Brave: Black Women's Studies (Old Westbury, N.Y.: Feminist Press, 1982). See for example the "most general statement of [their] politics" as being "actively committed to struggling against racial, sexual, heterosexual, and class oppression and see as our own particular task the development of integrated analysis and practice based upon the fact that major systems of oppression are interlocking. The synthesis of these oppressions creates the conditions of our lives" at 13 (emphasis mine).

10. Crenshaw, "Demarginalizing the Intersection of Race and Sex: A Black Feminist Critique of Antidiscrimination Doctrine, Feminist Theory and Antiracist Politics," 140.

11. Crenshaw, "Demarginalizing the Intersection of Race and Sex: A Black Feminist Critique of Antidiscrimination Doctrine, Feminist Theory and Antiracist Politics," 154.

12. Crenshaw, "Demarginalizing the Intersection of Race and Sex: A Black Feminist Critique of Antidiscrimination Doctrine, Feminist Theory and Antiracist Politics," 167.

13. Crenshaw, "Demarginalizing the Intersection of Race and Sex: A Black Feminist Critique of Antidiscrimination Doctrine, Feminist Theory and Antiracist Politics," 149.

14. Dagmar Schiek and Anna Lawson, "Introduction," European Union Non-Discrimination Law and Intersectionality: Investigating the Triangle of Racial, Gender and Disability Discrimination, eds. Dagmar Schiek and Anna Lawson (Farnham: Ashgate, 2011) 2.

15. Crenshaw, "Demarginalizing the Intersection of Race and Sex: A Black Feminist Critique of Antidiscrimination Doctrine, Feminist Theory and Antiracist Politics," 149.

16. I have borrowed this title from Julia S. Jordan-Zachery, "Am I a Black Woman or a Woman Who Is Black? A Few Thoughts on the Meaning of Intersectionality," Politics \& Gender 3.02 (2007).

17. Irene Browne and Joya Misra, "The Intersection of Gender and Race in the Labor Market," Annual Review of Sociology (2003).

18. Judith Squires, "Intersecting Inequalities: Reflecting on the Subjects and Objects of Equality," The Political Quarterly 79.1 (2008).

19. Jennifer C. Nash, "Re-Thinking Intersectionality," Feminist Review 89 (2008).

20. Kathy Davis, "Intersectionality as Buzzword: A Sociology of Science Perspective on What Makes a Feminist Theory Successful," Feminist theory 9.1 (2008).

21. Schiek and Lawson, "Introduction," 2.

22. Jordan-Zachery, "Am I a Black Woman or a Woman Who Is Black? A Few Thoughts on the Meaning of Intersectionality," 256.

23. Leslie McCall, "The Complexity of Intersectionality," Signs 30.3 (2005).

24. Jordan-Zachery, "Am I a Black Woman or a Woman Who Is Black? A Few Thoughts on the Meaning of Intersectionality," 256.

25. Jordan-Zachery, "Am I a Black Woman or a Woman Who Is Black? A Few Thoughts on the Meaning of Intersectionality," 261.

26. Ange-Marie Hancock, "When Multiplication Doesn’t Equal Addition: Examining Intersectionality as a Research Paradigm," Perspectives on Politics 5.1 (2007)..

27. Jordan-Zachery, "Am I a Black Woman or a Woman Who Is Black? A Few Thoughts on the Meaning of Intersectionality," 258.

28. McCall, "The Complexity of Intersectionality."

29. Dahlab v. Switzerland 2001 (ECtHR App. No. 42393/98)

30. Sahin v. Turkey 2005 (ECtHR App. No. 44774/98).

31. Schiek and Lawson, "Introduction," 1. 
32. Lynn Roseberry, "The Assimilationist Anti-Discrimination Paradigm and the Immigrant Muslim Woman: Suggestions on How to Re-Conceptualize Discrimination Claims," European Union Non-Discrimination Law and Intersectionality: Investigating the Triangle of Racial, Gender and Disability Discrimination, eds. Dagmar Schiek and Anna Lawson (Farnham: Ashgate, 2011).

33. Stephanie Fehr, "Intersectional Discrimination and the Underlying Assumptions in the French and German Headscarf Debates: An Adequate Legal Response?," European Union Non-Discrimination Law and Intersectionality: Investigating the Triangle of Racial, Gender and Disability Discrimination, eds. Dagmar Schiek and Anna Lawson (Farnham: Ashgate, 2011) 124

34. Erica Howard, Law and the Wearing of Religious Symbols: European Bans on the Wearing of Religious Symbols in Education (New York: Routledge, 2011).

35. Roseberry, "The Assimilationist Anti-Discrimination Paradigm and the Immigrant Muslim Woman: Suggestions on How to Re-Conceptualize Discrimination Claims," 191.

36. Howard, Law and the Wearing of Religious Symbols: European Bans on the Wearing of Religious Symbols in Education 127.

37. Crenshaw makes this point explicitly in her clear misgivings about critical legal theory not grasping the importance of racism in American society. I have written on the 'othering' of the Muslim woman in Europe elsewhere (see Sevda Clark, "Female Subjects of International Human Rights Law: The Hijab Debate and the Exotic Other Female," Global Change, Peace and Security 19.1 (2007).); suffice it to say here that its underlying assumptions have a densely woven history, having permeated literature and society stretching back centuries.

38. Anastasia Vakulenko, "Islamic Headscarves' and the European Convention on Human Rights: An Intersectional Perspective," Social \& Legal Studies 16 (2007): 191.

39. Kimberlé Williams Crenshaw, "Race, Reform, and Retrenchment: Transformation and Legitimation in Antidiscrimination Law," Harvard Law Review 101.7 (1988): 1381.

40. United Nations Committee on Economic, Social and Cultural Rights, 'General Comment No. 20: Non-Discrimination in Economic, Social and Cultural Rights (art. 2)' (2009) UN Doc $\mathrm{E} / \mathrm{C} .12 / \mathrm{GC} / 2 \mathrm{O}$.

\section{REFERENCES}

\. Abrams, Kathryn. "Hearing the Call of Stories." California Law Review 79.4 (1991): 971-1052 Print.

- Browne, Irene, and Joya Misra. "The Intersection of Gender and Race in the Labor Market." Annual Review of Sociology (2003): 487-513. Print.

-. Clark, Sevda. "Female Subjects of International Human Rights Law: The Hijab Debate and the Exotic Other Female." Global Change, Peace and Security 19.1 (2007): 35-48. Print.

- Crenshaw, Kimberle Williams. "Demarginalizing the Intersection of Race and Sex: A Black Feminist Critique of Antidiscrimination Doctrine, Feminist Theory and Antiracist Politics." The University of Chicago Legal Forum (1989): 139-67. Print.

-. Crenshaw, Kimberlé Williams. "Race, Reform, and Retrenchment: Transformation and Legitimation in Antidiscrimination Law." Harvard Law Review 101.7 (1988): 1331-87. Print.

-. Davis, Kathy. "Intersectionality as Buzzword: A Sociology of Science Perspective on What Makes a Feminist Theory Successful." Feminist theory 9.1 (2008): 67-85. Print.

-. Delgado, Richard. "Storytelling for Oppositionists and Others: A Plea for Narrative." Michigan Law Review 87.8 (1989): 2411-41. Print.

- Farber, Daniel A., and Suzanna Sherry. "Telling Stories out of School: An Essay on Legal Narratives.” Stanford Law Review 45.4 (1993): 807-55. Print.

- Fehr, Stephanie. "Intersectional Discrimination and the Underlying Assumptions in the French and German Headscarf Debates: An Adequate Legal Response?” European Union Non-Discrimination Law and Intersectionality: Investigating the Triangle of Racial, 
Gender and Disability Discrimination. Eds. Schiek, Dagmar and Anna Lawson. Farnham: Ashgate, 2011. 111-24. Print.

- Gilligan, Carol. In a Different Voice: Psychological Theory and Women's Development. London: Harvard University Press, 1982. Print.

- Hancock, Ange-Marie. "When Multiplication Doesn't Equal Addition: Examining Intersectionality as a Research Paradigm." Perspectives on Politics 5.1 (2007): 63-80. Print.

- Howard, Erica. Law and the Wearing of Religious Symbols: European Bans on the Wearing of Religious Symbols in Education. New York: Routledge, 2011. Print.

- Hull, Gloria T., Patricia Bell Scott, and Barbara Smith. All the Women Are White, All the Blacks Are Men, but Someof Us Are Brave: Black Women's Studies. Old Westbury, N.Y: Feminist Press, 1982. Print.

- Jordan-Zachery, Julia S. "Am I a Black Woman or a Woman Who Is Black? A Few Thoughts on the Meaning of Intersectionality." Politics \& Gender 3.02 (2007): 254-63. Print.

- Love, Jean. "The Value of Narrative in Legal Scholarship and Teaching." Journal of Gender Race \& Justice 87.2 (1998): 87-97. Print.

- Matsuda, Mari J. "Looking to the Bottom: Critical Legal Studies and Reparations." Harvard Civil Rights-Civil Liberties Law Review 22.2 (1987): 323-400. Print.

- McCall, Leslie. "The Complexity of Intersectionality." Signs 30.3 (2005): 1771-800. Print.

- $\quad$ Nash, Jennifer C. "Re-Thinking Intersectionality." Feminist Review 89 (2008): 1-15. Print.

- Rideout, Christopher J. . "Storytelling, Narrative Rationality, and Legal Persuasion." The Journal of the Legal Writing Institute 14 (1998): 53-86. Print.

- Roseberry, Lynn. "The Assimilationist Anti-Discrimination Paradigm and the Immigrant Muslim Woman: Suggestions on How to Re-Conceptualize Discrimination Claims.” European Union Non-Discrimination Law and Intersectionality: Investigating the Triangle of Racial, Gender and Disability Discrimination. Eds. Schiek, Dagmar and Anna Lawson. Farnham: Ashgate, 2011. 191-208. Print.

- $\quad$ Said, Edward W. Orientalism. N.Y.: Pantheon Books, 1978. Print.

- Schiek, Dagmar, and Anna Lawson. "Introduction." European Union Non-Discrimination Law and Intersectionality: Investigating the Triangle of Racial, Gender and Disability Discrimination. Eds. Schiek, Dagmar and Anna Lawson. Farnham: Ashgate, 2011. 1-8. Print.

- Sigerman, Harriet. The Columbia Documentary History of American Women since 1941. Columbia University Press, 2003. Print.

- Solórzano, Daniel G., and Tara J. Yosso. "Critical Race Methodology: Counter-Storytelling as an Analytical Framework for Education Research." Qualitative Inquiry 8.1 (2002): 23-44. Print.

- Squires, Judith "Intersecting Inequalities: Reflecting on the Subjects and Objects of Equality." The Political Quarterly 79.1 (2008): 53-61. Print.

- Vakulenko, Anastasia. "Islamic Headscarves' and the European Convention on Human Rights: An Intersectional Perspective." Social \& Legal Studies 16 (2007): 183-99. Print. 